\title{
Espacios de reforma para la infancia. Imaginando la Colonia de Menores de Marcos Paz (Buenos Aires, comienzos del siglo xx)
}

\author{
Reform Spaces for Children. Imagining \\ Marcos Paz's Children's Colony (Buenos \\ Aires, Early 20th Century)
}

\author{
María Carolina Zapiola \\ (D) 0000-0003-2662-8771 \\ Universidad Nacional de General Sarmiento, Argentina \\ czapiola@ungs.edu.ar
}

Resumen: El objetivo de este artículo es explorar las reflexiones de los funcionarios y profesionales argentinos preocupados por la cuestión de la "minoridad" acerca de la trascendencia de la dimensión espacial en los procesos de reeducación de los menores durante la primera década del siglo xx. Con ese fin, analizamos el proyecto de creación de la Colonia de Menores Varones de Marcos Paz, deteniéndonos en cómo fue imaginada en términos espaciales y arquitectónicos. Ello nos permite concluir que los proyectos argentinos de creación de instituciones para menores, inspirados en las propuestas europeas decimonónicas, estuvieron atravesados por una reflexión sistemática acerca de la trascendencia del espacio natural y del espacio arquitectónico en la regeneración del desvío infantil y juvenil. Se trata de la primera aproximación historiográfica que explora el penitenciarismo dirigido a niños y jóvenes, y una de las pocas centrada en el rol de los espacios en el diseño de las escuelas de reforma.

Palabras clave: espacio; menores; arquitectura; campo; reforma. 
Abstract: The purpose of this article is to explore the reflections of Argentinean officials and professionals concerned with the issue of minority on the importance of the spatial dimension in the reeducation of minors during the first decade of the 20th century. To this end, we analyzed the plans for the establishment of Marcos Paz' Male Minors' Colony, focusing on how it was conceived in spatial and architectural terms. We can infer from this that the Argentinean projects for the creation of institutions for minors, inspired by 19th-century European proposals, were shot through with a systematic reflection on the importance of natural and architectural space in the reform of children and youth. This is the first historiographical approach that explores penitentiary systems for children and young people, and one of the few focused on the role of spaces in the design of reform schools.

Key words: space; minors; architecture; countryside; reform.

Fecha de recepción: 29 de noviembre de 2016 Fecha de aceptación: 28 de junio de 2017

Llamamos... al establecimiento COLONIA DE MENORES VARONES,... aun cuando destinemos algunas de sus secciones para los encausados y condenados [porque] los reformatorios son instituciones equivocadas, incompletas, nocivas, contrarias á la intención que sus nombres indican é inexactas en sus nombres mismos, si no se los transforma en "educatorios", quitándoles todo indicio carcelario.

[...] Hacemos campear... el carácter eminentemente pedagógico de la Colonia en todos los preceptos propuestos: para los menores llevados ante la justicia, ella realizará la prisión de puertas abiertas. Nos esforzamos en desterrar cuanto pudiera recordar la prisión: nada de altos muros, ni rejas, ni gruesos barrotes en las ventanas; sus construcciones tendrán aspecto alegre; estarán rodeadas de plantas trepadoras, con patios circunscriptos por cercos verdegueantes, con horizontes vastísimos; la perspectiva del campo por ende... Y en todas partes profusión de aire, luz, verdura y flores

Meyer Arana (1906, pp. 4-8). 
on estas palabras el doctor Alberto Meyer Arana, médico, miembro de la
Comisión Directiva del Patronato de la Infancia (fundado en la ciudad de Buenos Aires en 1892), director de su órgano de difusión, la Revista de Higiene Infantil, autor de numerosos artículos y libros y, por todo lo anterior, referente en las políticas públicas internacionales de protección de la infancia, sintetizaba su concepción acerca de cómo debía organizarse la primera colonia de reforma para menores varones que estaba a punto de crearse en Argentina. ${ }^{1}$

Poco antes, el ministro de Justicia e Instrucción Pública, Joaquín V. González, miembro del ala liberal reformista de la oligarquía gobernante (Zimmerman, 1994), lo había convocado para diseñar la institución, que se emplazaría en el pueblo de Marcos Paz, ubicado a $50 \mathrm{~km}$ de la capital federal, al noroeste de la provincia de Buenos Aires. Como resultado, Meyer Arana elaboró Colonias para menores (1906) obra en la que revisaba con preciosismo las características de las principales instituciones de reforma existentes en Europa y Estados Unidos y proponía un diseño para la Colonia Agrícola Industrial de Menores Varones de Marcos Paz.

Para entonces se hallaba avanzado en Argentina, al igual que en otros países de América Latina (Azaola Garrido, 1990; Bailón Vazquez, 2012; Cabral dos Santos, 2006; Castillo Troncoso 2006; Hecht, 2002; Speckman Guerra, 2005; Vianna, 2007), Europa (Davin, 1996; Forlivesi, 2005; Jablonka, 2006) y en Estados Unidos (Pisciotta, 1994; Platt, 1997), el proceso de distinción entre los "niños" -menores de edad inscritos en el marco de las relaciones familiares, la escuela o el trabajo según su posición social-y los "menores" -niños y jóvenes que no encajaban en los roles que las elites estaban definiendo como los adecuados para la infancia en el marco de creación de un estado moderno-. Las características de sus hogares, sus estrategias de supervivencia, sus formas de sociabilidad y entretenimiento, sus prácticas sexuales, su relación intermitente con la escuela y su libre discurrir por las calles hacían prever su caída en el delito (Aversa, 2006; Carli, 2002; Carreras, 2005; Ciafardo, 1990; Freidenraij, 2015; Ríos y Talak, 1999; Ruibal, 1993; Zapiola, 2007). ${ }^{2}$

Ante la amenaza que representaban, los dispositivos tradicionales de tutela y punición, apoyados esencialmente en la beneficencia, comenzaron a

\footnotetext{
${ }^{1}$ Entre sus obras, Por el niño pobre (1904), La caridad en Buenos Aires (1911), Alrededor de los huérfanos (1923).

${ }^{2}$ En el entendimiento de que se trata de categorías socioculturales, en adelante prescindiremos del entrecomillado al utilizar los vocablos "menor", "niño" y afines con el propósito de agilizar la lectura.
} 
parecer insuficientes, además de inadecuados en relación con las propuestas jurídicas y científicas internacionales en boga, ancladas en el penitenciarismo y el positivismo. En ese clima de ideas y sensaciones, funcionarios y profesionales se dieron a la tarea de crear proyectos destinados a encauzar la conducta de los niños y los jóvenes preocupantes, vertebrando sus propuestas en torno a dos demandas que se verían prontamente satisfechas: el establecimiento de una Ley de Patronato de Menores (sancionada en 1919) que permitiría al Estado convertirse en tutor de los "menores material o moralmente abandonados" y/o "delincuentes" - lo cual implicaba la pérdida de la patria potestad de sus progenitores- y la creación de instituciones de reforma a las cuales enviarlos para garantizar su conversión en hombres de bien (Zapiola, 2014).

Así, en 1898 se inauguró la primera institución pública educativo-punitiva para niños y jóvenes de nuestro país, el Asilo de Reforma de Menores Varones, en pleno centro de la ciudad de Buenos Aires. Sin embargo, casi en seguida, los interpelados por la cuestión de la minoridad -incluyendo a las mismas autoridades del Asilo- reclamaron su traslado al campo, impulsando la inauguración de la Colonia de Marcos Paz. Sin dudas, el Asilo ofrecía infranqueables obstáculos para el plan de regeneración de la niñez "peligrosa y en peligro": emplazado en un edificio preexistente oscuro, inadecuado y estrecho, podía alojar una cantidad muy limitada de internos, no permitía aplicar la separación de los menores de acuerdo con la etiología de su desvío y casi no disponía de lugar para instalar talleres de trabajo (Zapiola, 2013).

Pero el interés por fundar una institución en el campo iba más allá de las limitaciones del Asilo. En efecto, en este artículo buscaremos demostrar que, durante la primera década del siglo $\mathrm{xx}$, los profesionales y funcionarios que irían convirtiéndose paulatinamente en especialistas o expertos en infancia y minoridad (entre ellos algunos médicos, pedagogos, directores de asilos, benefactores, jueces, defensores de menores, legisladores) comenzaron a reflexionar en forma sistemática acerca de la centralidad de la dimensión espacial en los procesos de reeducación de los menores. ${ }^{3}$ Lo hicieron inspirándose en experiencias europeas y estadunidenses, por lo cual, en el primer apartado, trazaremos un panorama de las mismas. ${ }^{4}$ En el segundo,

${ }^{3}$ Recién a partir de la década de 1920 podría hablarse con mayor precisión del nacimiento de una burocracia experta en cuestiones de minoridad. Desde luego, muchas de las figuras que podrían integrarse en este perfil eran, a la vez, profesionales y funcionarios.

${ }^{4}$ Aunque en otros países de Latinoamérica se estaban produciendo desarrollos institucionales y legales que buscaban responder a la cuestión de la minoridad (paro los casos 
exploraremos las particulares apropiaciones locales de esos modelos, para detenernos, en el tercer apartado, en el análisis del primer diseño conceptual de una escuela de reforma formulado en el país, es decir, en el proyecto para la creación de la Colonia de Menores Varones de Marcos Paz, complementado por el Reglamento de la institución.

Nuestro objetivo principal es analizar cómo fueron imaginados los espacios naturales y arquitectónicos en los que habitarían los menores, es decir, qué funciones se otorgaron al entorno natural y a la arquitectura en el primer proyecto argentino de creación de una institución de reforma. Intentaremos realizar, por lo mismo, un primer aporte acerca de lo que significó el penitenciarismo aplicado a niños y jóvenes en nuestro país, tema casi ausente en los campos de la historia de la infancia y de la historia del delito y del castigo. $\mathrm{Al}$ respecto, defenderemos la hipótesis de que, ya en el nivel conceptual, es decir, antes de su efectiva apertura, las escuelas rurales de reforma argentinas estuvieron atravesadas por contradicciones entre una utopía ruralista que apostaba a la regeneración de los niños y jóvenes colocados en "cottages" a cargo de "familias" por los efectos de la naturaleza y un modelo punitivo anclado en el penitenciarismo.

\section{PRISIONES, REFORMATORIOS, COLONIAS ${ }^{5}$}

La instalación de la "delincuencia juvenil" como un problema social constituyó el requisito para la creación de instituciones de reforma para niños y jóvenes. En la Europa del siglo XVIII, la creciente preocupación por las cuestiones de orden público y el ensalzamiento de los valores ligados a la economía y al trabajo reforzaron las actitudes represivas en relación con los vagos de todas las edades, propiciando la aparición de los hospicios generales, gigantescos lugares de encierro que, en el caso de Bicêtre o de la Salpêtrière,

mexicano y brasileño véase, por ejemplo, Azaola Garrido, 1990; Bailón Vásquez, 2012; Cabral dos Santos, 2006; Castillo Troncoso, 2006; Speckman Guerra, 2005; Vianna, 2007), durante la etapa de cristalización de la categoría menor y del trazado de las primeras políticas para menores, es decir, entre 1880 y 1920, los profesionales, benefactores y funcionarios argentinos no aludieron jamás a ellos (Zapiola, 2014). Por ello, y en pos de los intereses de este artículo, nos limitaremos a explorar el abanico de experiencias en las que los argentinos efectivamente abrevaron, destacándose entre sus influjos la colonia francesa de Mettray y el reformatorio neoyorquino de Elmira.

5 Para un desarrollo extendido de este apartado, véase Zapiola (2015a). 
por ejemplo, alojaban menores que a su salida solían ser deportados a las nuevas colonias americanas (Bourquin, 2007). Pero fue a partir de "la doble revolución", con su correlato de transformaciones sociales y políticas y de expresiones inauditas del descontento popular, cuando ciertos niños y jóvenes comenzaron a ser percibidos con especificidad dentro del universo de los seres inquietantes de las ciudades (Yvorel, 2005).

Tal "descubrimiento" propició la fundación de novedosas instituciones punitivas, entre ellas la de algunas famosas prisiones destinadas a la detención de niños y jóvenes, como la Petite-Roquette en París (1836) y Parkhurst en Inglaterra (1835). Basadas en el régimen de aislamiento celular y el sometimiento a una feroz disciplina, los niños, a partir de los seis o siete años y hasta los 20, tenían por todo contacto humano el encuentro, algunos minutos al día, con el personal de seguridad y, unos pocos minutos por semana, con el capellán (Pierre, 2005). A los ojos de sus encumbrados promotores y diseñadores -entre los que se destacaban figuras de la talla de Alexis de Tocqueville y Charles Lucas- los menores condenados, procesados y puestos en corrección paterna lograrían, a través de su inmersión en el aislamiento y el silencio, el recogimiento y la contrición necesarios para su enmienda (Bourquin, 2007).

Sin embargo, durante las décadas de 1830 y 1840, filántropos y algunos funcionarios comenzaron a defender la idea de que el joven delincuente era, ante todo, un niño, y como tal, debía ser educado en vez de castigado (Jablonka, 2005). Convencidos de que su aislamiento temporal tenía que darse bajo modalidades distintas a las de la prisión, dieron vida a las colonias agrícolas de reforma (Pierre, 2005). Su intención era sustraer a los niños y jóvenes "desviados" de la corrupción de las ciudades y conducirlos, por medio de su inserción en el mundo rural y de la adquisición de una formación agrícola, hacia los principios fundamentales de las sociedades primitivas: la salud, el orden, la moral y la economía. En esos nuevos espacios, el silencio redentor de la prisión celular sería reemplazado por la naturaleza redentora, que, en palabras de Auguste Demetz, fundador de Mettray: "inspira el temor a Dios y la sumisión a la autoridad" (Bourquin, 2007).

De las múltiples colonias fundadas al calor de este impulso, dos se transformaron en iconos de la educación residencial decimonónica: la Rauhe Haus (Hamburgo, 1833) y Mettray (Tours, 1839), fundadas respectivamente por el líder luterano Hinrich Wichern y por el juez y filántropo Auguste Demetz. Inspirada en su par alemana, Mettray se constituyó en el estableci- 
miento emblemático del movimiento de colonias agrícolas y penitenciarias privadas. Su director buscaba lograr una acción moralizadora profunda de los internos, para lo cual contaba con la localización en el campo-espacio cuya principal virtud estaba dada por constituir lo opuesto a la ciudad-, la terapéutica basada en el trabajo, la labor de un personal joven, formado en una escuela preparatoria creada para tal efecto, y la colaboración de los menores, cuyo corazón pretendía alcanzarse a través de una mayor vigilancia y una disminución de los castigos (Dekker, 2005; Pierre, 2005).

Para mediados del siglo XIX, entonces, se habían definido en Europa dos opciones punitivas para niños y jóvenes, resumidas en la fórmula "celda versus tierra”, pero también se habían desarrollado las críticas en torno a ambos modelos. Así, las prisiones para niños fueron vilipendiadas por practicar un sistema de aislamiento cruel y por no preparar a los internos para la vida en sociedad. A su vez, las colonias fueron criticadas por la contradicción que existía entre la procedencia urbana de sus pupilos y la educación agrícola a la que se los sometía, considerada inútil, ya que al finalizar su detención volverían al ámbito urbano. Además, se cuestionaba el desarrollo de colonias privadas por entender que el derecho de punición correspondía únicamente al Estado y por desconfiar de los filántropos "de viejo estilo", simples soñadores y demasiado liberales (Pierre, 2005).

Para ese momento, el movimiento en pro de las escuelas de reforma también tomó impulso en Estados Unidos. En efecto, con posterioridad a la guerra civil (1861-1865), esa clase de instituciones se instaló en el imaginario de los sectores dirigentes como el lugar privilegiado para la reeducación de los niños y jóvenes desviados, pues los tradicionales valores estadunidenses encarnados por el hombre de campo protestante se veían amenazados por la conjunción de urbanización, industrialización e inmigración masiva y por el incremento del crimen, la pobreza y la decadencia moral, requiriendo una renovación de las instituciones represivas (Pisciotta, 1994; Schlossman, 1998).

A diferencia de lo que sucedió en Europa, las prisiones para niños estadunidenses fueron usualmente inauguradas por los poderes públicos en el ámbito urbano, pese a lo cual no fue extraño un cofinaciamiento público-privado, ni que el control de las escuelas fuera ejercido por comités municipales de ciudadanos respetables. Variopintos en su diseño arquitectónico y a los métodos disciplinarios, educativos y religiosos que ensayaron para la rehabilitación de los jóvenes, los reformatorios estadunidenses se nutrieron de los diseños y realizaciones filantrópicas transatlánticas. Además, compartieron 
con ellas la amplitud de su clientela, compuesta por un grupo heterogéneo de niños de las clases bajas, que incluía a los condenados por la comisión de delitos, pero también a aquellos cuya conducta incorregible permitía predecir futuros conflictos con la ley, y a otros cuyas opciones estaban tan circunscriptas por la pobreza y por los malos ejemplos que encarcelarlos constituía un "acto de caridad" necesario para prevenir una vida de pobreza y crimen (Schlossman, 1998).

En ese marco, las escuelas de reforma se expandieron por todo el país, salvo en el sur, rezagado en términos de desarrollo institucional. Pero su veloz difusión no impidió que, para 1880, se hubieran convertido en el blanco de las críticas de penólogos y educadores. Entre sus aspectos negativos, se destacaba que ofrecían a los padres la tentación de desligarse de la responsabilidad de criar a sus hijos, que sometían a los jóvenes y relativamente inocentes reclusos a las influencias educativas y los avances sexuales de los delincuentes de mayor edad, que provocaban un estigma irrevocable sobre los internos que entorpecía su reintegración en la sociedad y que trataban a los sujetos en masa y no individualmente. Es decir que, por su misma naturaleza, eran incapaces de preparar a los niños para la vida fuera del establecimiento (Schlossman, 1998).

La crisis de las escuelas rurales europeas tampoco se hizo esperar. Con la llegada del segundo imperio (1852-1870) el Estado francés asumiría progresivamente el control del universo punitivo para niños y jóvenes, y las colonias -multiplicadas en las décadas previas- entraron en crisis luego de que sucesivas inspecciones revelaran las terribles condiciones de vida de los colonos, la violencia de los métodos disciplinarios, el estado de insalubridad de los establecimientos y su desorden administrativo, todo lo cual condujo a su clausura o a "dejarlas morir" suspendiendo el envío de detenidos, y por ende, de subsidios estatales. Por otro lado, las concepciones referidas a la infancia estaban variando y condujeron, en el pasaje entre los siglos XIx y xx, a la sanción de nuevas leyes que afirmaron la protección de la infancia como principio y establecieron la educación primaria universal, el patronato estatal de los menores huérfanos y abandonados, la reglamentación del trabajo infantil y, para los transgresores de la ley, los tribunales especiales para menores y la libertad vigilada en el seno familiar. En ese contexto, las colonias dejaron de ser entendidas como estrategias "familiares" de regeneración y pasaron a ser concebidas como espacios de abusos y carencias (Bourquin, 2007; Chavaud, 2005; Pierre 2005). 
En suma, para fines del siglo xIX se habían instalado, a nivel internacional, dos modelos de escuela de reforma que, opuestas a las prisiones para niños, aspiraban a la reeducación de la infancia caracterizadas como "inocente y culpable": el sistema congregate o de reformatorios, que aceptaba la vida conjunta de amplios y heterogéneos grupos de niños en grandes edificios, en general urbanos, así como arreglos laborales muy variados que podían concretarse dentro o fuera de la institución, y el sistema cottage, que proponía la convivencia de grupos reducidos de niños en pequeños "hogares" o en colonias localizados en áreas rurales en los que habitarían y trabajarían bajo la supervisión de una pareja subvencionada por el Estado, o de personal que cumpliría las funciones parentales. Sin embargo, para esa fecha, ambas se hallaban en crisis y eran objeto de virulentas críticas.

\section{LAS PARTICULARES APROPIACIONES ARGENTINAS}

El hecho de que el desarrollo y la entrada en crisis de la colonia y del reformatorio fueron procesos simultáneos no podría deducirse de los discursos de los funcionarios y profesionales argentinos, que presentaron sistemáticamente a las colonias rurales como un relevo cronológico, pedagógico, organizativo y humanitario con respecto a las perimidas escuelas de reforma urbanas:

Hoy son vetustos los asilos urbanos de pisos superpuestos, propensos á la formación de verdaderos hacinamientos que repudian las teorías y la higiene condena, porque en ellos no siempre hay el aire necesario ni es tan puro cual lo han menester los protegidos, de pobreza física ingénita, como que son producto del conventillo, nacidos entre la necesidad y las privaciones. El niño de precario desarrollo por miseria orgánica reclama el ambiente sano del campo para sus obligadas convalecencias.

Allí aprenderá lo necesario para llevar, mañana, luces de civilización y progreso á nuestros desiertos territorios nacionales (Meyer Arana, 1906, pp. IV a VI).

¿A qué se debió esta particular lectura de los desarrollos institucionales internacionales? La defensa de las elites locales de la colonia rural nos remite a las particularidades que informaron sus apropiaciones de las propues- 
tas internacionales de tratamiento de menores. En tal sentido, es innegable que los especialistas locales se incorporaron tarde a un debate de décadas, cuya principal demostración, para comienzos del siglo $\mathrm{xx}$, era que tanto el congregate como el cottage system eran capaces de generar toda clase de abusos y fracasos. Mas no se trata aquí de señalar la necesaria falta de linealidad entre los derroteros extranjeros y los locales explicándola en función de supuestos retrasos o falencias de esas apropiaciones, sino de explorar sus razones y especificidades.

En Argentina, en el marco de la cristalización de una cultura científica (Terán, 2000), los representantes de las diversas disciplinas que se fueron definiendo, quienes muchas veces ocuparon cargos públicos, comenzaron a insertarse en una red de circulación y reformulación transnacional de saberes, debates, propuestas y realizaciones (Ben Plotkin y Zimmermann, 2012; Neiburg y Ben Plotkin, 2004). En esa trama se fueron integrando los incipientes especialistas interesados en la infancia y la minoridad por medio de viajes, presentaciones a congresos internacionales, visitas de destacadas figuras extranjeras a las nacientes o renovadas instituciones educativas y centros de investigación locales y, quizás el factor más importante, a través de lecturas y producciones escritas. En tal sentido, las revistas oficiales y académicas, como El Monitor de la Educación Común desde la década de 1880, los Archivos de Psiquiatría, Criminología y Ciencias Afines desde 1902, y los Archivos de Pedagogía y Ciencias Afines desde 1906 constituyeron, junto con los libros, algunos de los vehículos privilegiados a través de los cuales figuras como Meyer Arana, Rodolfo Senet o Víctor Mercante, entre otros, divulgaron las teorías científicas y los modelos institucionales extranjeros ocupados de la infancia. ${ }^{6}$

${ }^{6}$ Víctor Mercante (1870-1934) egresó de la Escuela Normal del Paraná y trabajó como Director General de Escuelas en San Juan, donde en 1891 creó el primer laboratorio de psicofisiología experimental. Se desempeñó luego como director de la Escuela Normal de Mercedes (Buenos Aires) y dirigió la Sección Pedagógica de la Facultad de Ciencias Jurídicas de la Plata entre 1906 y 1914, que constituyó la base para el establecimiento de la Facultad de Ciencias de la Educación, de la cual fue decano. Asimismo, dirigió los Archivos de Pedagogía y Ciencias Afines y los Archivos de Ciencias de la Educación y se desempeñó como inspector general de enseñanza secundaria (Santillán, 1959). Rodolfo Senet (1872-1938), quien dio forma de disciplina a la psicología infantil en nuestro país, egresó de la Escuela Normal de Profesores de Buenos Aires, fue secretario y profesor de la Escuela Normal de Mercedes, ocupó distintos cargos directivos en escuelas normales y fue nombrado Director de Instrucción Pública por el Ministro de Justicia e Instrucción Pública Saavedra Lamas en la década de 1910 (Carli, 2002). 
De modo que los profesionales y funcionarios argentinos interpelados por la cuestión de la minoridad empezaban a disponer de una cuantiosa información referida a las escuelas de reforma, a pesar de lo cual puede cuestionarse su conocimiento del desempeño cotidiano de las instituciones emblemáticas de Occidente. Ello resulta comprensible si se tiene en cuenta que las instituciones de mayor fama mundial lo fueron, en parte, porque sus directores-fundadores llevaron adelante exitosas campañas de propaganda, consistentes en editar y publicar favorables memorias anuales que distribuían entre los más encumbrados representantes del mundo intelectual y político $y$ en los congresos internacionales, en contrarrestar con éxito las denuncias por abusos y malos tratos que las pusieron bajo la lupa de la prensa y las autoridades y en cultivar amplias redes de apoyo político y económico. Así operó Demetz, y también lo hizo Zebulon Brockway, uno de los más destacados penólogos estadunidenses, quien entre 1876 y 1900 dirigió el Reformatorio de Elmira, Nueva York, el segundo establecimiento más sistemáticamente evocado por los expertos argentinos después de Mettray.

Es muy posible, entonces, que los profesionales y funcionarios argentinos no hayan podido atravesar la coraza constituida por la imagen positiva que protegía a estas y a otras instituciones de ser destituidas del podio de la vanguardia reeducativa. ¿Cómo acceder, de hecho, a los dantescos informes presentados por la New York State Board of Charity que, en 1893 y 1894 , pusieron en entredicho cada aspecto del funcionamiento de la vanagloriada Elmira y revelaron que se trataba de una cárcel infernal, si los mismos fueron dejados sin efecto por el gobernador del Estado, repudiados por el New York Times y publicados sólo en diarios de segunda línea? (Pisciotta, 1994). Por otra parte, si bien las campañas de prensa dirigidas contra las colonias rurales en Francia comenzaron en la década de 1880, las que tuvieron en la mira a Mettray -y condujeron a su cierre en 1937- se desarrollaron recién a partir de 1909, a raíz del suicidio de un interno (Chauvaud, 2005; Pierre, 2005). De modo que el abrazo argentino de la opción rural a comienzos de siglo no resultaba extemporáneo.

Con todo, el problema de la apropiación y la recreación de ideas y realizaciones extranjeras no puede reducirse a determinar cuánto sabían los especialistas y funcionarios locales de lo que sucedía en otros países y cómo accedían a ese conocimiento, sino que impone reflexionar acerca de cómo y para qué utilizaron ese saber. Un ejemplo puede iluminar esta cuestión. Como ya mencionamos, Elmira fue, junto con Mettray, el establecimiento 
más invocado por los profesionales y funcionarios argentinos como modelo a seguir. Tal elección, empero, resulta incomprensible si se tiene en cuenta que el reformatorio neoyorquino no era una colonia rural y que no estaba destinado a niños y jóvenes parangonables a los menores, sino a los young offenders, es decir, a sujetos de entre 16 y 30 años que hubieran delinquido por primera vez, a los que se buscaba separar de los adultos que ya habían hecho una carrera en el delito. Ese establecimiento, además, se regía por el sistema de encierro celular, por la regla del silencio diurno, por una preponderancia aplastante del trabajo sobre la educación y, desde 1888, año en el que quedó prohibido el trabajo de los internos por la presión de industriales y sindicatos obreros, por el reemplazo del trabajo por un rígido régimen militar, según el cual los presos pasaban entre cinco y ocho horas diarias marchando y realizando maniobras militares (Pisciotta, 1994).

Se trataba de elementos denostados en su totalidad por los profesionales y funcionarios argentinos. ¿Por qué, entonces, tenían sus ojos puestos en Elmira? Es poco probable que desconocieran los aspectos organizativos formales de la institución. No obstante, algunos de sus rasgos los atraían sobremanera: en ella regían la sentencia por tiempo indeterminado y el sistema de libertad condicional, sujetos a los designios de la dirección y supervisados por un patronato de egresados, dos acariciadas aspiraciones de los reformadores locales del sistema carcelario. Por otra parte, en sus discursos nunca se hizo alusión a que la Colonia de Mettray fuera una institución privada y religiosa. Funcionarios y profesionales coincidían en que, en nuestro país, las instituciones destinadas a la reforma de menores varones serían controladas por el Estado. La beneficencia, las órdenes religiosas y los particulares podrían seguir ocupándose de los niños pequeños y de las niñas, pero no de sujetos peligrosos que requerían un tratamiento científico para ser enmendados. $^{7}$

En definitiva era posible recortar, de un vasto universo de ideas y modelos, aquellos que, se creía, eran más necesarios o más fáciles de adaptar a las idiosincrasias nacionales. Pues, si las colonias agrícolas, como concepto y como instituciones en funcionamiento, se hallaban en crisis en otras latitudes, o si en sus orígenes habían surgido como iniciativa de filántropos cristianos -circunstancias a las que nunca se hizo referencia en los discursos

\footnotetext{
${ }^{7}$ Para las estrategias público-privadas de amparo y corrección de mujeres menores, véase Caimari (2007), Feidenraij (2012), Guy (2001).
} 
argentinos- nada permitía suponer que, bien llevadas, no resultarían un éxito en las nuevas repúblicas, donde los jóvenes Estados tenían todo por hacer. Tales expectativas se colmarían de sentido en un clima de revalorización del campo que adquirió relieves superlativos en el ámbito nacional.

Desde luego, el proceso argentino de ensalzamiento intelectual del espacio rural y de instalación del tópico de la ciudad como vicio no pueden desvincularse del derrotero de ambas ideas en Europa y Estados Unidos durante los siglos XVIII y XIX (Schorske, 1987). Sin embargo, la formulación local de imágenes de lo rural y de lo urbano hundió sus raíces en un vasto suelo de experiencias particulares, ajenas $y$, muchas veces, opuestas, a las de la modernidad europea. De hecho, entre nosotros, el campo no fue en un principio un espacio y un tiempo a los cuales retornar, sino un desierto que requería una intervención militar y cultural, pero sobre todo política, para convertirse en campo, como explica Fermín Rodríguez:

"Desierto" es el nombre para una ausencia de política, una operación discursiva con el poder de atrapar la imaginación al evocar, en negativo, la plenitud ausente de un estado-nación por venir: donde había virtualmente un desierto -multiplicidades salvajes sin orden ni medida, mundos posibles, pueblos futuros- el Estado-nación debía advenir [...]

El desierto no sólo le proporciona a la nación el soporte territorial necesario para trazar sus límites geográficos, también le sirve para la figuración de un vacío, de una carencia... que la constitución del estado vendría a reparar. Al cuerpo lleno de la tierra virgen, en tanto unidad primitiva y salvaje de producción... le falta algo: un estado. El Estado es entonces lo que le falta al desierto...: una unidad trascendente superpuesta a la unidad inmanente de la tierra, sobrecodificando las corrientes de capitales nacionales y extranjeros, volcando flujos humanos, de herramientas y de enunciados sobre un extenso plano que previamente se había encargado de vaciar (Rodríguez, 2010, pp. 15 y 397 ).

A finales del siglo XIX, varios elementos se conjugaron para permitir la conversión simbólica y material de este desierto en un suelo fértil para la colonización y para el cultivo. En ese proceso fue decisiva la nueva política militar frente al "indio" encarada por el ministro de Guerra -y futuro presidenteJulio A. Roca, que, imprimiendo un giro notable en las estrategias que por décadas habían seguido los gobiernos nacionales y porteños, basadas en diferentes formas de contacto y colaboración con los "indios amigos", puso a las 
comunidades indígenas pampeanas y patagónicas frente al imposible dilema de la cautividad o la muerte, poniendo los territorios que hasta entonces habían controlado a disposición de "la nación" (Rodríguez, 2010; Mases, 2002).

Por su parte, las inmensas transformaciones demográficas, económicas, culturales y sociales acaecidas en Buenos Aires y en otras ciudades del litoral atlántico (Romero, 1994) impulsaron la reformulación de la dicotomía decimonónica que enfrentaba la campaña bárbara con la ciudad luz. En el pasaje entre dos siglos, toda una gama de violencias y amenazas, generalmente nuevas, fueron relocalizadas en los bajos fondos del espacio urbano (Caimari, 2004; Gayol, 2000). Paralelamente, un campo finalmente desprovisto de peligros fue tornándose en un espacio moralizador y terapéutico en virtud de sus cualidades intrínsecas, y convirtiéndose en la solución para enfrentar problemáticas tan diversas -aunque interrelacionadas en las representaciones de las elites-como la reforma de los delincuentes (especialmente los niños y jóvenes), el fortalecimiento de los niños débiles (Di Liscia, 2005) o la provisión de un repertorio de imágenes "nacionales" capaces de conjurar el caótico cosmopolitismo de las principales urbes argentinas (Prieto, 1988).

Las expresiones vertidas por los impulsores de la Colonia de Marcos Paz constituyeron manifestaciones elocuentes de estas variaciones de la sensibilidad en relación con el campo. El propio Adolfo Vidal, enfático propagandista de los progresos que el Asilo de Reforma había realizado bajo su dirección entre 1901 y 1903, desplegó grandes esfuerzos para "arrancar este Establecimiento exótico de la Capital Federal y plantarlo en su medio vital y fecundo del campo", ya que según entendía:

con la tierra se relacionan en consorcio estrecho y armónico las ideas de luz, calor, aire, agua, planta, animal, arma [sic], hogar, familia, sociedad, patria, ciencia y Dios", por lo que "curar el mal... á todo ese elemento desviado por la ociosidad y el abandono paterno" [requería]... abandonar el circuito estrecho de la Capital Federal, y buscar en el campo, el trabajo amplio que ha de tener la virtud de purificar las costumbres y enjendrar en esos excluídos de la sociedad, hábitos de trabajo y aptitudes para la lucha por la vida, con provecho para el Estado.

Aquí, todo está en contra de los fines que se buscan.

El edificio inadecuado, húmedo, medioeval, carcelario y mortificante.

El personal administrativo y docente, en su mayoría ocasional y sin vocación, y por lo tanto, sin estímulos, sin hábitos, sin carácter y sin fe. 
Las familias de los recluidos en contacto domadario [sic] con éstos, destruyendo con perverso instinto toda tendencia de regeneración.

Los oficios que se les enseñan, agotados por la competencia de un emporio que se cambia de manufacturero en fabril.

El medio ambiente saturado de alicientes, deletéreos, corruptores y propicio á la cultura de los vicios que se les quiere extirpar ó corregir.

$\mathrm{Y}$ ante todo, y sobre todo, la carencia de la tierra, cuyo cultivo bondadoso ofrece al recluido su porvenir y su redención. ${ }^{8}$

Por su parte, Meyer Arana sintetizaba la fe de los contemporáneos en las mutuas potencialidades redentoras del niño sobre el campo y del campo sobre el niño:

Al huérfano recogido por la caridad ly a los niños de tutela pública, pupilos de las Defensorías y salpicados por el delito], hay que substituirle[s] el techo común de las grandes construcciones escolares, por el campo con sus cielos azulados y darle el horizonte de las pampas incultas, pródigamente generosas con quienes escarban sus entrañas; y las riquezas de los bosques inexplorados; y los panoramas de los ríos y de los arroyos, compensadores de las tareas emprendidas en las soledades del desierto [...] Para él la conquista del inmenso desconocido, allá lejos, donde la Patria necesita las avanzadas de sus hijos... (Meyer Arana, 1906, pp. IV a VI).

En su mirada, el "inmenso desconocido" se convertía en un espacio óptimo para la vida humana, "en una configuración de nexos morales, afectivos e intelectuales que se presentaban como más dignos y humanos" que los propios de su espacio opuesto, la ciudad (Sarlo, 2003, p. 33). En vista de esas cualidades regeneradoras, no es extraño que el filántropo, que en sus discursos se refería de modo menos drástico, tajante, frío e impersonal -es decir, de modo más amoroso- que sus contemporáneos positivistas a los niños y jóvenes objeto de su interés, formulara la propuesta más radical de extrañamiento de los menores de sus círculos de sociabilidad, al sugerir su envío a

8 Asilo de Reforma. Memorias del Ministerio de Justicia, Culto e Instrucción Pública (1901), pp. 81 y 82. Nos ha sido imposible recabar información sobre Adolfo Vidal. Sólo sabemos que este médico se desempeñó como director del asilo en el periodo señalado, imprimiendo un giro positivista en la organización y los objetivos de la institución (Zapiola, 2013). 
recónditos territorios aún vacíos de población, de los cuales se convertirían en habitantes permanentes luego de su reeducación. Después de todo, gobernar era poblar el inmenso y "vacío" territorio de la nación (Pérez, 2014).

Y si bien Marcos Paz no se hallaba en los parajes remotos de la patria, sino en la benigna región pampeana, el pueblo en cuyas afueras se decidió instalar la Colonia se encontraba a suficiente distancia de la ciudad de Buenos Aires -50 kilómetros-, en términos geográficos y de accesibilidad, y estaba tan poco desarrollado, como para poder cumplir la función de desarraigo de los menores de sus redes de sociabilidad, sus vínculos afectivos y sus hábitos, entendidos por científicos y benefactores como los causantes de su desvío. Fundado oficialmente en 1878 , el verdadero nacimiento del partido se produjo en 1870, cuando el primer tren del ramal Merlo-Lobos, perteneciente al Ferrocarril del Oeste, arribó a la flamante estación Coronel Doctor Marcos $\mathrm{Paz}$, que tomó su nombre del recientemente fallecido vicepresidente (figura ligada a la localidad) y dio su denominación al pequeño pueblo que comenzó a crecer a su alrededor y a transformarse de zona de graserías y hornos de ladrillos en zona agrícola-ganadera. Con el tren arribaron los primeros inmigrantes, que se asentaron con emprendimientos hortícolas y ganaderos, sumándose a las estancias dedicadas al ganado vacuno, y para el centenario habían adquirido gran importancia los tambos, en su mayoría propiedad de inmigrantes vascos (Achucarro, 2009; Moliné de Berardoni, 1978).

Pese a estos significativos cambios, en 1900 El Argentino, órgano de prensa de la región, afirmaba que las calles del pueblo resultaban intransitables de día por el barro y de noche por la falta de luz. Tales deficiencias persistieron hasta entrada la década de 1930, cuando se concretaron los primeros proyectos de pavimentación de las calles, colocación de baldosas en las veredas y construcción de una sala de primeros auxilios. Si los caminos en el casco urbano de Marcos Paz eran muy malos, llegar hasta la institución, ubicada a 16 kilómetros del pueblo, era una misión francamente difícil. El traslado de los futuros internos y de los visitantes se efectuaba en carros que partían desde el playón del Ferrocarril, y desde allí, de acuerdo al estado de un camino surcado por tres intransitables pantanos, tardaban entre una hora y media y dos horas y media en llegar, que se sumaban a las largas horas de viaje desde Buenos Aires (Achucarro, 2009). ${ }^{9}$

9 Hoy en día sigue siendo difícil acceder desde la ciudad de Buenos Aires hasta la actual Colonia Hogar Ricardo Gutiérrez. Una vez que se llega al pueblo de Marcos Paz, el cami- 
Pero estas circunstancias no desalentaron a sus impulsores. Al contrario, como había sucedido en la tradición europea, lo fundamental, en su imaginario, era la localización rural de la Colonia, pues ella permitiría per se alcanzar una serie de metas que en la capital resultaban irrealizables. Para comenzar, ofrecía la posibilidad de aislar a los niños del decadente ámbito urbano y, sobre todo, de sus familias, reputadas como las principales responsables de todos los males que los afligían. Se suponía, además, que las autoridades no habrían de padecer las limitaciones edilicias que obstaculizaban el desarrollo de cualquier proyecto acabado de regeneración en Buenos Aires, ya sea porque podría derivarse a las instituciones rurales la cantidad de niños y jóvenes que se considerara necesario sin tener que ajustarse a un límite inamovible de vacantes, ya porque en sus amplias instalaciones podrían construirse toda clase de talleres. Por último, se creía que la disponibilidad de espacio permitiría situar separadamente a los distintos tipos de menores (huérfanos y abandonados, encausados y condenados), paso indispensable para proceder a la ansiada especialización del castigo (Meyer Arana, 1906).

\section{UNA PRISIÓN DE PUERTAS ABIERTAS}

Fuera de los círculos más comprometidos con la creación de la Colonia, cuyos miembros solían extenderse en un abanico de motivos, el resto de las voces oficiales tendió a apoyar el proyecto del presidente de la nación, Julio A. Roca y su ministro del Interior, Joaquín V. González, concentrándose en la urgencia de separar a los niños huérfanos y abandonados de los menores delincuentes y encausados, con los que convivían en las defensorías, las comisarías, los depósitos de encausados y el Asilo de Menores. Esa fue la línea argumentativa que siguió el senador Salvador Maciá cuando lo presentó en la Cámara Alta, para lo cual se valió de un informe elaborado por el director especialista inglés Mateo Embley.

En efecto, un tiempo antes, cuando se tomó la decisión de organizar casas correccionales para menores, el entonces ministro de Justicia Juan M. Fernández le encargó al ministro de Inglaterra que buscara "un hombre de

no de $16 \mathrm{~km}$ que conduce hasta la institución no está asfaltado, está rodeado de descampado y punteado por grandes basurales, y el servicio de transporte público hacia la misma es de baja frecuencia. 
reputación, de práctica reconocida y recomendado por todos los antecedentes para ponerlo al frente de los establecimientos que iban á crearse", contratándose a Embley como resultado. ${ }^{10}$ En su informe, Embley describía con tonos lúgubres la situación de los menores encerrados en los asilos de la nación, entre los que incluía el Asilo de Reforma. Se trataba de establecimientos en los que se hallaban mezclados niños de siete y ocho años, "que no tienen más delito que no tener padre ni madre y que no tienen en esos pretendidos asilos de corrección de la Nación nada que hacer más que aprender vicios y malas costumbres que puede presumirse los conocen ya; pero [...] allí los perfeccionan", con "criminales de 16, 17 y 18 años". ${ }^{11}$ Apoyándose en estos datos, harto denunciados y conocidos por los argentinos pero revestidos ahora, al parecer, de una pátina de prestigio al ser esgrimidos por una figura de calibre internacional, el senador Maciá exigió que se dejara de sostener lo existente y se aprobara la fundación de la Colonia. Tras unas pocas intervenciones, limitadas a inquirir acerca de la extensión y el costo del terreno en el que se instaló la Colonia y a objetar el hecho de que el poder ejecutivo nacional lo hubiera comprado sin autorización del Congreso, el proyecto fue aprobado, siendo su tramitación aún más rápida en la Cámara de Diputados.

De este modo quedaba sancionada la Ley núm. 4522, que autorizaba al poder ejecutivo nacional a instalar una colonia agrícola industrial de "menores varones" en la provincia de Buenos Aires. El artículo $2^{\circ}$ de su Reglamento establecería mayores precisiones sobre su población, que estaría compuesta por los menores encausados y condenados de diez años en adelante y por los mayores de ocho años remitidos por los jueces en corrección paterna, por los enviados con arreglo al artículo $20^{\circ}$ de la Ley de Educación Común para hacer efectiva su asistencia a la escuela, por los depositados por los defensores de menores, por los remitidos por la policía "moral o materialmente abandonados", por los huérfanos colocados por sus tutores o guardadores y por los colocados por sus padres indigentes o inhabilitados para alimentarlos o para educarlos con autorización del Ministerio de Justicia e Instrucción Pública. ${ }^{12}$

${ }^{10}$ Comunicaciones oficiales. Diario de Sesiones de la Cámara de Diputados. Año 1904. (1904, t. I, sesión del 6 de septiembre de 1904).

11 Comunicaciones oficiales. Diario de Sesiones de la Cámara de Diputados. Año 1904. (1904, t. I, sesión del 6 de septiembre de 1904, p. 430).

${ }^{12}$ Reglamento de la Colonia de Menores Varones establecida en Marcos Paz, provincia de Buenos Aires, por decreto del poder ejecutivo nacional del 28 de junio de 1905. En Jorge y Meyer Arana (1908). 
Así, contradiciendo explícitamente los planes de remitir a Marcos Paz sólo a los menores "no delincuentes", la heterogeneidad de la población se erigió en un elemento constitutivo de la institución. Heterogeneidad que, no obstante, sería sistemáticamente horadada por una sorda tendencia que homologaba a los niños y jóvenes en su condición de menores institucionalizados. Mas, a los efectos prácticos, esa contradicción estructural entre una institución destinada a captar una población dispar que al mismo tiempo aspiraba a la especialización del tratamiento y del castigo debía resolverse ¿cómo hacerlo? Siendo un hombre implicado en la "gestión" de la infancia desde hacía tiempo, Meyer Arana encontró una manera de congeniar aspiraciones tan discordantes. Así, fundiendo elementos de diversas experiencias institucionales europeas, propuso organizar la Colonia según un "sistema de familias" que permitiría la separación de distintos tipos de menores en diferentes secciones, con lo que se dejaba "justificada la razón del art. $2^{\circ}$ [del Reglamento] que para algunos podría presentarse como almácigo informe" (Meyer Arana, 1906, p. 22).

Señalar que en el imaginario de los impulsores de Marcos Paz -en este caso, de su principal ideólogo- convivieron modelos institucionales superpuestos contribuye a entender las dificultades organizativas que, durante las dos décadas siguientes, serían características de la Colonia (Zapiola, 2014). Y nos advierte sobre la improcedencia de cualquier análisis que explique el devenir histórico de las instituciones a partir de las distancias entre proyectos presuntamente acabados y coherentes y praxis que, por diversos motivos, se alejan de los mismos. En efecto, si se contrasta el plan formulado por Meyer Arana en Colonias para menores (1906) con su plasmación en el Reglamento, puede apreciarse que en esta instancia fundacional, es decir, antes de la apertura del establecimiento y en la pluma de su mismo autor, se plantearon expectativas organizativas irreconciliables. Es que la traducción de un texto filosófico, científico, pedagógico o político -y Colonia para menores tenía un poco de todos ellos-, de un lenguaje argumentativo, descriptivo e incluso ampuloso, al lenguaje burocrático asumido por un reglamento, que debe ser lo más esquemático y "universalmente" comprensible para resultar operativo, era acción llamada a desnaturalizar el proyecto original.

Como hemos visto, Meyer Arana argumentaba que la protección y la moralización de la infancia en la Colonia de Marcos Paz se lograrían gracias a la impresión de un sesgo pedagógico y "familiar" a la nueva institución, a través del cual debía diferenciarse rotundamente de los reformatorios. 
Ambos podrían garantizarse por medio de la implantación del "sistema de familias", cuyo funcionamiento en gran parte de las instituciones europeas repasaba, aunque se detenía en la dinámica que había adquirido en "la ponderada" colonia suiza de Bachtelen. Con una población total que no excedía los 60 niños, las agrupaciones por sección nunca contaban allí más de 20 menores, siendo admirables los resultados obtenidos:

Cada grupo tiene su departamento separado, con su dormitorio, toilette, ropero y sala de trabajo, y está dirigido por un jefe que cuida el primero, vigila el estudio, y sirve en el comedor á los menores, con quienes come en la misma mesa. Para aproximarse á la realidad de la familia, se ponen juntos niños de distintas edades, que vienen á ser los hermanos mayores y menores del hogar común. Durante el día van á sus clases y ocupaciones respectivas; los grandes con los grandes, los chicos á las de los pequeños, como los niños de una misma casa que concurren á la escuela ordinaria, pero en seguida toda la familia se halla reunida con su jefe durante las comidas, horas de estudio y recreos que el tiempo obliga á pasar en lugares cerrados. Con esta descripción, copiada de buena fuente, queda bosquejada la organización interna propuesta para la Colonia. Es también el programa de Mettray sin su criticada militarización (Meyer Arana, 1906, pp. 8 a 12).

Para ilustrar sus objetivos, Meyer Arana se refería también

á las dos célebres escuelas fundadas por el Dr. Reddie en Abbtosolmo y por su discípulo Badley en el Sussex... [que] no se parecen á los grandes edificios escolares, fríos y desnudos; son dos cotagges ingleses. Producen la sensación de la vida real y no de una vida artificial; recuerdan el aspecto de la casa paterna, no el de un cuartel, ni el de una prisión. La primera ojeada exterior determina la impresión de una residencia agradable [...]

La impresión persiste cuando se penetra en el interior. He aquí el comedor de la escuela de Bedales: es por completo una habitación de familia, alegre y confortable; los útiles elegantes, la mesa cubierta con mantel; el mobiliario cuidado y artístico; un piano, cuadros, estatuas, butacas, acreditan la doble preocupación de lo agradable y lo útil [...]

Pero [la idea del sistema de educación que se debe seguir] será aún más viva, si se añade que los profesores y el director de la Escuela, su mujer y sus hijos, hacen sus comidas con los alumnos, vida en familia; si el niño no se 
ve así substraído á la vida real, no se le transporta á un mundo aparte y por completo artificioso; sólo pasa de un home á otro [...]

Es tanto más oportuna esta reproducción, cuanto que no hemos de omitir esfuerzo por dar al establecimiento de Marcos Paz un carácter pedagógico por excelencia, de tal suerte que la escuela anule y ahogue todo posible resabio de prisión común, sin pretender por esto, colocar á los hijos del delito en condiciones superiores á las de que goza el hijo honesto del obrero común.

Formemos ambiente al menor para enseñarle á vivir con honradez; pero no pretendamos respete los manjares teniéndolo en ayunas; será un vano empeño superior á su naturaleza (Meyer Arana, 1906, pp. 8-9). ${ }^{13}$

¿A qué obedecía semejante minuciosidad en la descripción de los entornos en los que se desarrollaban las actividades de los colonos de instituciones europeas? La propuesta de Meyer Arana ganaba en autoridad cuantos más referentes extranjeros exitosos evocaba. Por otra parte, su discurso tenía vocación pedagógica: debía hacer conocer a los principales funcionarios de la nación un tipo de institución con la que no estaban familiarizados y convencerlos de las ventajas que suponía implantarla en territorio argentino. Pero su detenimiento en la descripción del ambiente natural, la arquitectura y la vida cotidiana de las colonias estaba ligado a una razón más profunda: su fe en las virtudes pedagógicas y terapéuticas de la naturaleza y la arquitectura, su creencia de que la construcción de un placebo de hogar requería estudiar cuidadosamente sus dimensiones espacial y material, porque estas darían sustento, a su vez, a los lazos que pudieran tejerse entre sus miembros.

En efecto, para él, la organización y el uso de los espacios constituían elementos clave en el plan de "relevamiento físico y moral" de los menores, y no un simple contexto en el cual este se desarrollaría. Por ello insistía en que, en la instalación de la Colonia, no podría apelarse a procedimientos improvisados, pues todo recurso "acomodaticio y provisorio" adquiría luego un carácter definitivo y permanente, llegando a "petrificarse en modo tal, que la realidad de la obra queda luego reducida á ridícula parodia de la iniciada" (Meyer

${ }^{13}$ Nótese cómo el tema de las condiciones adecuadas de encarcelamiento se complica por el principio de "less eligibility". Idea que databa del siglo XIX, suponía que las condiciones de los presos no debían ser preferibles ni más confortables que las de los miembros peor situados de la comunidad que no habían sido condenados por un crimen. Caso contrario, estas supondrían un incentivo positivo para los ciudadanos más pobres para delinquir y mejorar sus condiciones (Scholssman, 1998). 
Arana, 1906, p. 85). Para prevenir esa - profética- eventualidad, y confiando en que para la "instalación material" de los principios que reglamentarían la institución se convocaría a expertos, describió puntillosamente los espacios físicos en cuyos marcos debían llevarse a cabo las actividades cotidianas de los menores. Inspirándose en los modelos disponibles, delineó un establecimiento dividido en pabellones, propuso que estos estuvieran reunidos en una especie de aldea o pueblo rural y los inscribió en un entorno natural.

En vista de la relevancia que el médico argentino otorgó al espacio en el cual se iba a aplicar el programa reeducativo, no parece casual que su referente principal fuera Mettray, ya que la escuela de reforma francesa había sido producto del esfuerzo imaginativo y conceptual conjunto de un magistrado, Auguste Demetz, y un arquitecto, Abel Blouet. ${ }^{14} \mathrm{Al}$ igual que Meyer Arana, los fundadores de la colonia gala habían confiado en los valores morales de la arquitectura y en el impacto positivo que la misma podría tener sobre los espíritus y los corazones de los colonos. En tanto se buscaba excluir al encierro de su programa regenerativo, el diseño de su plano general no podía inspirarse en el modelo de la prisión, y menos aún en el del panóptico, prevaleciente en la arquitectura penitenciaria estadunidense y europea de la época. Siguiendo entonces el ejemplo de la colonia hamburguesa de Horn, se adoptó el modelo de pabellones, que pasaron a denominarse "casas", dada la importancia de brindar a los colonos el sentimiento de pertenecer a una familia, en tanto la colonia fue concebida como un "pueblo" o ciudad en miniatura (Saunier, 2005).

La elección de un sistema constituido por pabellones paralelos entre sí, y dispuestos en forma simétrica a ambos lados de un eje que pasaba por una capilla, no sólo se hallaba inscrita en la larga tradición utópica de la ciudad ideal, sino que fue sugerido también por la naciente arquitectura hospitalaria. En efecto, Mettray constituyó el primer ejemplo de "arquitectura neumática”, es decir, de arquitectura que permitía que el aire circulara entre sus construcciones, y a los ojos de los contemporáneos -en especial a los de Blouet y sus colegas- su plano seguramente evocaba un hospital. Es por ello

${ }^{14}$ Es de destacar que en el proceso de creación de la colonia no se registra la presencia de arquitectos. La posición de los médicos también fue central en el proceso de diseño de edificios escolares acordes a los objetivos del proyecto nacional de creación de un sistema de instrucción pública, en el cual figuras como el médico higienista Francisco Súnico ocuparon un lugar central (Barbieri, 2014), 
que la colonia debe entenderse no sólo como una escuela, sino además como un espacio de curación, en este caso, moral (Saunier, 2005).

Gran conocedor de esta y de otras experiencias internacionales, y revelando una aguzada lucidez con respecto a los posibles obstáculos para su remedo en Argentina, "donde no siempre se ha consultado lo necesario en las construcciones especiales", Meyer Arana afirmaba que, para la instalación de la colonia de Marcos Paz, resultaba indispensable la preparación de un plano de conjunto en el cual figuraran los edificios existentes y se determinara la ubicación de los futuros. Debía considerarse que la colonia recibiría menores "de distinta condición y procedencia, de situaciones personales diversas cuando no encontradas (condenados, encausados, de simple abandono moral ó material) que necesitan instalaciones adecuadas", que llegarían a un total de 1000 o 1500 (Meyer Arana, 1906, pp. 86-87). Teniendo en cuenta ambas variables, estableció que, con base en "cada categoría de menores", se formarían secciones separadas e independientes, de 50 alumnos como máximo cada una, lo que habilitaría a los prefectos, sus encargados, a practicar los principios familiares. ${ }^{15}$

Salvo en el caso de las secciones de ingreso, de condenados y de indisciplinados, que deberían situarse en los extremos más alejados del predio, con límites claramente definidos y obstáculos que las tornaran inaccesibles y evitaran las fugas, el resto de las secciones podían ubicarse cerca de la Dirección, es decir, en el centro del predio. Cada una se instalaría en un edificio sencillo pero elegante, y contaría con un gran comedor para 70 personas (sumando los 50 colonos y el personal), muy amplio, para que pudiera servir de sala de reunión en los días de lluvia y de sala de lectura o biblioteca por la tarde y noche. El mismo comunicaría directamente con la cocina, y esta, a su vez, tendría anexada una despensa, ambas inaccesibles para los menores. Próxima al comedor se encontraría la sala de baños y lavatorios, con acceso independiente del que tendría desde los dormitorios, y un cuarto para desvestirse con desagüe en el centro, a fin de que los colonos pudieran higienizarse al regresar de sus faenas sin tener que pasar por los dormitorios (Meyer Arana, 1906, pp. 89 a 93).

${ }^{15}$ Reglamento de la Colonia de Menores Varones establecida en Marcos Paz, provincia de Buenos Aires, por decreto del poder ejecutivo nacional del 28 de junio de 1905. Cap. I, Del Establecimiento, art. $5^{\circ}$, p. 375 ; y cap. XVI, De los prefectos, art. $81^{\circ}$. En Jorge y Meyer Arana (1908). 
Los menores dormirían en dos habitaciones con capacidad para 25 camas cada uno, cuyas dimensiones se calcularían de modo que permitiera la instalación de alacenas de 70 centímetros de ancho, destinadas a guardar las ropas de los adjudicatarios de acuerdo con el principio individualista. Resultaba necesario elevar la dignidad de los "huéspedes" de Marcos Paz permitiendo que formaran conciencia de su "yo". Para ello era necesario que cada interno dispusiera de su propia cama y de sus propias ropas, a diferencia de lo que sucedía en otras instituciones, en las que el vestuario era común. Ello garantizaría un cuidado de las prendas y, por este medio, un aprendizaje de lo que significaba la propiedad. Finalmente, los dormitorios deberían orientarse de modo tal que recibieran los primeros rayos de sol, y en sus extremos se dispondrían celdas, baños y servicios especiales para el personal inferior del establecimiento (Meyer Arana, 1906, p. 94). ${ }^{16}$

Las instalaciones mencionadas, "indispensables para los fines propuestos, dentro de una economía que evite todo gasto superfluo", serían complementadas por un molino, un lavadero y por el departamento del prefecto, que constaría de un despacho, tres habitaciones de familia, cuarto de baño, accesorios y pieza de servicio, y que sería "de incomunicación insalvable” con el resto de la sección (Meyer Arana, 1906, p. 97). Representante del director, el prefecto habitaría en ella junto a su familia, y ejercería la autoridad superior e inmediata sobre los menores y empleados. A ellos les estaba confiada la mejora moral y material de "sus" menores, respecto de los cuales debían desempeñarse "como buenos padres de familia", inculcarles sanos principios y enseñarles con el ejemplo, estableciéndose en tal sentido que debían inspirar "la suficiente confianza como para que los menores les tengan cierta familiaridad respetuosa, nacida en su carácter de protectores decididos, siempre dispuestos á acudir en su ayuda, á ampararlos y á velar por su porvenir". Por otra parte, debían asegurar que reinara la mayor higiene y orden en sus dependencias, llevar el registro de "sus" menores, disponer de la buena preparación de los alimentos y de su distribución, comer con los menores, "interrogarlos... en desempeño de su alta misión tutelar", imponer las penitencias por las faltas que denunciaran los maestros, capataces

${ }^{16}$ Meyer Arana llegaba a describir los materiales y formatos con los que deberían construirse los pisos, las celosías de las ventanas o dónde debía haber mangueras para garantizar la higiene. Por motivos de espacio, se han privilegiado otros aspectos más relevantes para este análisis. 
y celadores y vigilar su ejecución, ordenar el cumplimiento de los horarios, mantener la disciplina, "revistar á sus menores en formación" por la mañana y por la tarde y acompañarlos a todos los actos a los que concurrieran "en corporación". ${ }^{17}$

Un pequeño jardín, bien delineado y cuidado, serviría de marco a cada una de las secciones, llamadas a provocar el cambio "físico y moral" de sus moradores. Esa transformación se fomentaría también por medio de "máximas" y "simples inscripciones" que se colocarían en las paredes del comedor y los dormitorios, tales como "dios-patria-hogar-virtud-honradez-trabajo-perseverancia-ganarás el pan con el sudor de tu frente-el trabajo dignifica...” (Meyer Arana, 1906, p. 76), práctica característica en las instituciones afines de Occidente. Por otra parte, las secciones estarían separadas por avenidas, de las cuales partirían calles que conducirían a la escuela, la capilla y la sala de actos: "bien arboladas, con plantaciones de naturaleza distinta, estas avenidas [darían] al núcleo central de la colonia un aspecto atrayente, seductor y de bienestar. Como los edificios serían distintos, porque ninguna razón justificaría la construcción de dos iguales, pues la arquitectura es rica en estilos... semejará un rincón amable del más amable de los pueblos veraniegos". Por último, en el plano se debería ubicar la enfermería - con una pequeña sala de aislamiento, sala de enfermos no contagiosos y Botica-, la escuela, la capilla, la sala de actos, los talleres industriales, las canchas de juego al aire libre, las piletas de natación, cocheras y caballerizas, las secciones de avicultura, sericultura, apicultura y selvicultura, la porqueriza, los tambos, las cremerías, los palomares, los depósitos generales para los frutos e implementos usados en la agricultura (rodados, herramientas), los bañaderos y galpones para los animales y la carnicería (Meyer Arana, 1906, p. 91).

En la propuesta de Meyer Arana, las dimensiones ética y estética resultaban inseparables: "el buen gusto contribuye á elevar el espíritu y una instalación confortable hace olvidar las miserias morales de la vida. Lo bello y lo bueno son distintas manifestaciones de la verdad, y la verdad es el fin último de toda existencia bien encaminada". Por otra parte, si la Colonia lograba ser "un verdadero pueblo lleno de variantes", ello repercutiría en forma positiva

${ }^{17}$ En las secciones de encausados y condenados los prefectos se hallarían auxiliados por subprefectos, responsables inmediatos de la seguridad y jefes de los celadores. Reglamento de la Colonia de Menores Varones establecida en Marcos Paz, provincia de Buenos Aires, por decreto del poder ejecutivo nacional del 28 de junio de 1905, cap. xvi, "De los prefectos", arts. $83^{\circ}$ y $85^{\circ}$. En Jorge y Meyer Arana (1908). 
sobre el personal, que podría sacar el máximo provecho de sus instalaciones, debiendo poner para ello sentimiento, acción, voluntad, constancia y hasta el mismo corazón, en el cumplimiento de una elevada y honrosa tarea (Meyer Arana, 1906, pp. 91 y 96).

Así, adelantándose a lo que, pocos años después, sería característico de los discursos de los especialistas argentinos en minoridad, los de Meyer Arana estaban ya, a comienzos de siglo, plagados de metáforas domésticas. Ello se debía, sin duda, a su inscripción en una tendencia transnacional según la cual, durante la segunda mitad del siglo XIX, tanto los sostenedores del congregate como los del cottage system empezaron a servirse de imágenes y de vocablos tales como "familia", "hogar", "amor" y "educación" para describir sus metas y sus prácticas, y para presentar a las escuelas de reforma por medio de una retórica coherente con los patrones sentimentales de su tiempo (Schlossman, 1998, p. 332). ${ }^{18}$ El hecho de que, en Argentina, el sistema de reeducación de menores que propiciaban los impulsores de la Colonia fuera insistentemente descrito y caracterizado por medio de imágenes y metáforas familiares también se hallaba en relación con los desarrollos legales y socioculturales locales referidos al proceso de definición, reglamentación y ensalzamiento de un nuevo tipo de familia, que en ese momento estaba siendo impulsado desde distintas instancias estatales y profesionales (Nari, 2004).

Detengámonos, por ejemplo, en el análisis de la figura del prefecto. Pueden trazarse algunos paralelos entre los deberes y acciones que se esperaban de aquel funcionario - parangonables, a su vez, a los del director-y los que atañían a los padres. En efecto, sus funciones contemplaban las principales atribuciones otorgadas al pater familias en el Código Civil: la autoridad en el hogar y el derecho de criar a los hijos, educarlos y satisfacer sus necesidades de alimentos, vestidos y vivienda, que tenían como corolario la obligación de los hijos de respetar y obedecer al padre, conductas - ¿sentimientos?- que también se esperaba que desarrollaran los menores hacia los prefectos (Código Civil de la República Argentina, 1923, lib. I, sec. II, tít. III). Asimismo, la indicación de que el prefecto estaba llamado a despertar en sus menores "suficiente confianza" y "cierta familiaridad respetuosa", nacidas de su carácter protector, parece evocar la figura paterna. Con todo, se trata de

\footnotetext{
${ }^{18}$ En el original, aparece la palabra "nuture", que en español puede ser traducida como "crianza" "educación" y "alimentación" (en el sentido de nutrición). Optamos por la acepción "educación" en tanto es, de las tres, la palabra más reiterada entre los especialistas argentinos.
} 
una comparación difícil de realizar, ya que, como ha señalado Isabella Cosse, en nuestro país, la centralidad de la figura de la mujer para la comprensión de las dinámicas familiares ha relegado el estudio de la paternidad, por lo cual lo que sabemos sobre las conductas y formas de sensibilidad paternas de la etapa depende mucho más de los discursos críticos de quienes, durante las décadas de 1950, 1960 y 1970, las estereotiparon negativamente como estrategia para legitimar un nuevo modelo de paternidad, que de trabajos sistemáticos de investigación (Cosse, 2010).

Con cautela entonces, podría aventurarse que la imagen del padre puesta en valor en el cambio de siglo, severo pero afectuoso y distante del denunciado "despotismo paterno colonial", impregnó la de todas las figuras masculinas encargadas de ayudarlo -o de suplirlo- en su misión de educar y proteger a los niños y jóvenes, e incidió en la caracterización del personal que llevaría adelante la experiencia de Marcos Paz. Así, al igual que él, los maestros, los jueces, los funcionarios de instituciones de menores y los pediatras varones se constituyeron como personajes definidos por la posesión de la autoridad y requeridos de sentir afecto por los niños y de expresarlo a través del cumplimiento de sus deberes (proveer instrucción, alimento, vestimenta, salud, un futuro), más que por medio de efusiones sentimentales, asociadas con la naturaleza femenina y las funciones maternas (Nari, 2004).

Ahora bien, ¿cuánto del plan basado en un "sistema de familias" propuesto en Colonias para menores quedaba en pie cuando el mismo se plasmaba en términos reglamentarios? Poco o nada. Ante todo, porque la figura materna, pieza maestra del nuevo modelo familiar y presencia reclamada en forma explícita por Meyer Arana, permanecería ausente, o sería marginal, en un entorno institucional esencialmente masculino. A lo sumo, el prefecto viviría en cada sección acompañado por su familia "á la que hará partícipe, en cuanto sea posible, de la obra de relevamiento que le está confiada", ${ }^{19}$ pero la presencia de las "madres artificiales" no estaba garantizada, ni se le atribuían funciones específicas.

Pero había más: antes de arribar a ese incierto placebo de hogar que sería su sección, el menor debía atravesar una experiencia que, ahora sí, distaba por completo de cualquier modelo familiar. Se trataba de su permanencia

\footnotetext{
19 Reglamento de la Colonia de Menores Varones establecida en Marcos Paz, provincia de Buenos Aires, por decreto del poder ejecutivo nacional del 28 de junio de 1905, cap. XVI, "De los prefectos", arts. $81^{\circ}, 82^{\circ}$ y $83^{\circ}$. En Jorge y Meyer Arana (1908).
} 
en la llamada Sección de Ingreso, estimada en dos meses de duración, que serían empleados "en inculcar principios de moral en "los reclusos". Sujetos a la autoridad de un prefecto, los menores serían ocupados con preferencia en ejercicios militares "con el propósito de inculcarles hábitos de disciplina", alojados individualmente en celdas separadas y sometidos a un silencio "de rigor" en el refectorio. La clara impronta penitenciaria que modelaba la Sección de Ingreso se maridaba con el vocabulario y el estilo castrense presentes en otros apartados del Reglamento, en los que se preveía, entre las obligaciones de los menores, "vestir el uniforme reglamentario y presentarse aseados en todas las revistas" y "acatar sin vacilaciones y dar cumplimiento sin dilación á toda orden que emane de un superior" ${ }^{20}$ A todas luces, la orientación hogareña y pedagógica que Meyer Arana buscaba imprimir a la institución, y su explícito rechazo de la prisión, se diluían, en su propia propuesta, al entrar en competencia con la imaginería y las tradiciones penitenciarias y militares de reciente o actual constitución en el país.

El peso de estas últimas también quedaba de manifiesto por el tipo de tratamiento burocrático del que serían objeto los menores al ingresar a Marcos Paz, que replicaba el implementado en las comisarías y prisiones para identificar a otros "sujetos peligrosos". Como ha demostrado Mercedes García Ferrari, a partir de las últimas décadas del siglo xIX, al calor de dramáticas transformaciones demográficas y sociales que multiplicaban diariamente las caras desconocidas que habitaban los espacios urbanos, se tornó central para el Estado argentino desplegar estrategias de identificación de las personas, que en principio se dirigieron a delincuentes y transgresores, reales o presuntos. A tal efecto se recurrió, entre otras innovaciones, a técnicas orientadas a individualizar a los sujetos y al diseño de sistemas de clasificación y archivo que permitieran relacionar a las personas con los registros en papel conservados en los repositorios estatales (García Ferrari, 2010).

En ese marco, la Sección de Ingreso de la Colonia, "destinada á la investigación prolija y completa de su persona [la del menor] y de la de sus padres, para efectuar su inventario físico, intelectual y moral antes de disponerse su incorporación á la sección que se le designe", fue concebida como un espacio

${ }^{20}$ Reglamento de la Colonia de Menores Varones establecida en Marcos Paz, provincia de Buenos Aires, por decreto del poder ejecutivo nacional del 28 de junio de 1905, cap. II, "Del Ingreso de los menores", art. $15^{\circ}$, p. 377 y cap. III, "Obligaciones de los menores", art. $18^{\circ}$, incs. $3^{\circ}$ y $6^{\circ}$, p. 378. En Jorge y Meyer Arana (1908). 
en el que se desplegaría la batería de técnicas disponibles para la identificación y la clasificación de los sospechosos y delincuentes. En la misma se formaría un expediente de cada menor en el que quedarían agregados, "en cuanto sea posible", una serie de significativos elementos: la orden de ingreso o testimonio de la sentencia otorgado por la autoridad de la que provenía y los antecedentes del menor que poseyera dicha autoridad; documentos relativos a su persona; el resultado de un examen médico "prolijamente efectuado"; observaciones antropométricas con la ficha de su configuración craneana tomada con el conformador; impresiones dactiloscópicas; dos fotografías faciales tomadas de frente y de perfil "y una general ó local en los casos de sujetos anormales"; inscripciones podográficas; el resultado "del examen de su estado moral" y de sus sentimientos religiosos; el examen intelectual con el agregado de una plana caligráfica en el caso de los que supieran escribir; el resultado de las "observaciones diurnas y nocturnas" efectuadas durante el tiempo que el menor permaneciera en la Sección de Ingreso; el certificado de defunción del padre, de la madre o de ambos y, por último, los "antecedentes hereditarios debidamente comprobados" y el "estado moral y material de la familia, con especificaciones de todos los detalles que figurarán en la planilla especial". En este expediente se irían agregando, además, todas las referencias importantes sobre la vida del menor en la Colonia (distinciones, penitencias, aplicación trimestral en los talleres y las clases, "mejoras operadas en su carácter y tendencias y aspiraciones que se le hubieran notado") y, a su egreso, la constancia del resultado de la acción de patronato intentada y ejercida sobre el mismo. ${ }^{21}$

Durante los primeros años de funcionamiento de la Colonia, en un contexto de performance deficitaria de todas sus secciones, no se pudieron llevar adelante semejantes evaluaciones de los internos. Sin embargo, la propuesta de hacerlo es en sí misma sugerente, pues supone que quienes la formularon (Meyer Arana, el ministro Joaquín V. González que aprobó el plan y el Reglamento) tenían en mente un modelo institucional que preveía la implementación de las técnicas destinadas a la identificación de sujetos peligrosos al trazar estrategias educativas para los menores.

No es posible, ni ha sido nuestra meta, comparar la totalidad de las previsiones y propuestas formuladas en Colonias para menores (1906) por Me-

${ }^{21}$ Reglamento de la Colonia de Menores Varones establecida en Marcos Paz, provincia de Buenos Aires, por decreto del poder ejecutivo nacional del 28 de junio de 1905, cap. II, "Del

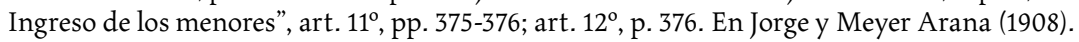


yer Arana con las disposiciones de su Reglamento. Lo que nos ha interesado, en cambio, es señalar las tensiones que atravesaron el modelo institucional constituido por las colonias agrícolas de reforma; inconsistencias presentes en la propia teoría, o derivadas de la traducción de un gran plan de un lenguaje más complejo -el de su fundamentación científico-filosófica- a otro más sencillo y operativo -en este caso, un reglamento institucional.

¿Por qué explorar este tipo de contradicciones? Porque ellas incidieron en las definiciones de la minoridad, en las características que asumieron las políticas públicas para menores y en los resultados que podían esperarse de las mismas. En efecto, la pretensión de hacer congeniar en un único modelo un proyecto de reeducación de los menores basado en su inserción en los marcos de familias sustitutas dedicadas a la agricultura -es decir, en su conversión en "niños" en el marco de familias "normales"- con el hecho de que, por una parte, esas "familias" estarían compuestas por agentes estatales remunerados -en su mayoría, o en su totalidad, varones- que desempeñarían principalmente funciones disciplinarias, y de que, por otra parte, los "hogares" serían secciones dentro de una institución de encierro, difícilmente podía materializarse. De un lado se hallaba una utopía ruralista; del otro, una intención punitiva anclada en el penitenciarismo. Cuando llegó la hora de poner a prueba este heterogéneo conglomerado de ideas y aspiraciones, y surgió una legión de obstáculos para hacerlo (como sucedió durante los primeros 20 años de vida de la Colonia), la segunda tendencia sería más fácil de concretar que la primera, en tanto existían precedentes y experiencias contemporáneas que podían imitarse (Zapiola, 2014).

El impulso punitivo se impondría, además, porque, incluso los abanderados de las políticas más vanguardistas para menores, partían de una estigmatización extrema de los niños objeto de su atención, que ningún rapto de paternalismo de los que solían colarse en sus textos lograba opacar. En tal sentido, son significativos los términos en los que Meyer Arana explicaba por qué los menores llegados a Marcos Paz debían pasar un tiempo en una Sección Especial de Ingreso. Analizando los desafíos que postulaba su "regeneración", encontraba que los recién llegados arribaban con una carga que podía poner en riesgo el proceso de "relevamiento" en curso de los demás asilados:

el asilado ingresa con hábitos y tendencias asimiladas en su abandono prematuro, y en esas condiciones debe ser puesto junto á menores ya iniciados en 
la vida moral de pupilaje. Ese contacto ofrece dificultades: el último huésped puede renovar, con sencillas conversaciones, recuerdos quizá adormecidos. Un noviciado ó periodo de observación, tiene así explicada su conveniencia: antes de incorporar á un menor, debe efectuarse su desinfección moral.

[...] Tenemos para nosotros por enfermos morales á todos los pequeños asilados, cualquiera sea su origen. Y como las afecciones de la voluntad, del carácter, de las tendencias, de los hábitos mal dirigidos, de las pasiones violentas y rastreras que señalan faltas de ideales levantados y de horizontes en la vida, sin afectos, aspiraciones, ni fines, en opinión universal de los entendidos son siempre virulentas, habrá de evitarse todo contacto inmediato é iniciarse la profilaxis consiguiente: primero se efectuará la antropometría moral del enfermo y se buscará su medida física para incorporársele después al grueso de los menores (Meyer Arana, 1906, pp. 12-15, cursivas mías).

La condena de todo lo implicado en la subjetividad y en el medio social de origen de los niños y jóvenes caracterizados como menores era absoluta. Un programa reeducativo anclado en el contacto profundo con la naturaleza y enmarcado en un "hogar" cuidadosamente diseñado en términos arquitectónicos y organizativos, ofrecería sustento material y espiritual a los nuevos seres en los que debían ser transformados.

\section{CONSIDERACIONES FINALES}

En el cambio de siglo, la inexistencia de espacios en donde colocar a la creciente cantidad de niños y jóvenes que quedaban a disposición de los defensores de menores, figuras que fungían como articuladores del entramado público-privado de asistencia y punición de los menores de edad "huérfanos", "abandonados", "vagos", "viciosos" y "delincuentes", presionó en favor del diseño y apertura de las primeras escuelas de reforma para menores. El influjo teórico del positivismo y el penitenciarismo resultó esencial en ese proceso (Zapiola, 2013).

Sin embargo, poco se sabe acerca de qué significó el penitenciarismo aplicado a la reforma y el castigo de los niños y los jóvenes. Este artículo es un primer aporte para explicarlo. Para ello presentamos, en forma esquemática, la historia de las instituciones de menores en las naciones que resultaron modélicas para las elites argentinas, y analizamos los motivos que condujeron a 
los incipientes expertos en minoridad a abrazar la opción educativo-punitiva representada por las colonias rurales siendo que, como establecimos, no era la única disponible y se hallaba en crisis. Luego, nos detuvimos en el proyecto de creación de la Colonia de Menores de Marcos Paz, inquiriendo en los modos en que fue proyectada espacial y arquitectónicamente y dando cuenta de cómo, ya en las formulaciones conceptuales inaugurales de la institución, se fueron plasmando contradicciones llamadas a repercutir en su funcionamiento cotidiano.

La indagación, basada en el análisis de textos escritos -ya que no existen fotografías, planos, ni otras fuentes iconográficas anteriores a la década de 1920 - nos permitió ponderar la importancia acordada a la dimensión espacial en los programas de reforma de menores. En efecto, para los impulsores argentinos del cottage system, el "campo" no era un mero contexto en donde emplazar los establecimientos reeducativos, ni las "casas" que constituirían cada "sección" simples lugares para dormir o comer. Por el contrario, figuras como Meyer Arana y el ministro González adjudicaron al ambiente natural y a la arquitectura funciones terapéuticas cruciales para la reeducación moral de los niños y jóvenes desviados, adelantándose a lo que 20 años más tarde sería común entre los expertos en minoridad: las colonias rurales permitirían su desapego de las sociabilidades urbanas erradas, y prometían transformarlos, por las propias virtudes de la naturaleza y por el tipo de vínculos que los "colonos" tejerían en sus nuevos "hogares", en hombres de bien. ${ }^{22}$

En términos más amplios, esta exploración refrenda la hipótesis general, que hemos sostenido a lo largo de nuestra investigación de doctorado, de que, en sus formulaciones modernas, la niñez y la infancia inscribieron e inscriben la posibilidad de ser imaginadas, interpeladas, gestionadas y vividas en la existencia de seres de corta edad, en las representaciones y discursos que las tienen como objeto pero, sobre todo, en el recorrido de ciertos es-

${ }^{22}$ Del mismo modo, los médicos y pedagogos vinculados al sistema de instrucción pública en construcción asignaron un lugar esencial a la arquitectura escolar y a los espacios verdes en la formación moral, física e intelectual de los alumnos (Pineau, 2014). Llamativamente, los textos de Meyer Arana no retoman ninguna de las propuestas generadas en ese ámbito por las máximas figuras del higienismo escolar. Quizá sea este un síntoma, junto a tantos otros, de la progresiva escisión simbólica entre el universo de la escuela común y el de las escuelas de reforma. Profundizar en su historia desde el punto de vista espacial, arquitectónico y material requerirá trazar diálogos con dos campos de estudios incipientes en Argentina: la historia de la arquitectura penitenciaria (García Basalo y Mithieux, 2017) y la historia del proceso de escolarización desde una dimensión estética (Pineau, 2014). 
pacios y decursos institucionales prefigurados socialmente, entre los cuales el pasaje por la escuela ha sido y sigue siendo el más trascendente. En este marco, dotar a la minoridad de entidad y de especificidad con respecto a la infancia "normal" requirió de un proceso de ideación y de creación de espacios particulares por los cuales los menores debían transitar, destacándose entre ellos la institución de reforma (Zapiola, 2014).

Lo específico de nuestro país es que, desde comienzos del siglo xx y por varias décadas, la institución de reforma rural se erigió en el modelo ideal de establecimiento para menores. Y si bien durante sus primeros 20 años de existencia la Colonia de Menores de Marcos Paz se desenvolvió como un compendio de carencias, abusos e ineficiencias, a sideral distancia del plan trazado por Meyer Arana, a lo largo de esos años la propuesta institucional de Meyer Arana se fue imponiendo, hasta constituirse en el corazón de la reforma estructural a la que fue sometida la Colonia -rebautizada como Colonia Hogar Ricardo Gutiérrez en 1924- y en el motor para la creación de establecimientos similares en la provincia de Buenos Aires a partir de los años veinte (Zapiola, 2015b). ${ }^{23}$

La pervivencia de la utopía pedagógica ruralista, y del otorgamiento de capacidades regenerativas al espacio rural, aún puede entreverse en la profusión de "granjas" terapéuticas y/o punitivas, privadas o públicas, destinadas a "albergar" a jóvenes y adultos procesados o condenados por la comisión de delitos, o a jóvenes con problemas de adicción a las drogas. Todavía hoy, las colonias y las granjas se presentan evocando la apuesta antiinstitucional que les dio vida. Nacidas con base en el rechazo de otro tipo de establecimiento denostado (el reformatorio, la prisión) siguen prometiendo constituirse en un espacio ideal de regeneración contrapuesto al deletéreo espacio urbano. Siguen apostando a ser el imposible oxímoron soñado por Meyer Arana: una prisión de puertas abiertas.

${ }^{23}$ En otros países de América Latina también comenzaron a fundarse instituciones de reforma urbanas y rurales desde fines del siglo XIX, pero, al parecer, no hubo una predilección intelectual hegemónica tan marcada por el cottage system. Al menos esto puede deducirse a partir de Azaola Garrido, 1990; Bailón Vazquez, 2012; Cabral dos Santos, 2006; Vianna, 2007. 


\section{LISTA DE REFERENCIAS}

Achucarro, M. (2009). Hechos, personajes y estampas del pueblo de Marcos Paz. De la Cañada de la Paja al Pueblo del Árbol [mimeo]. Buenos Aires: s. p. i.

Azaola Garrido, E. (1990). La institución correccional en México: una mirada extraviada. México: Siglo XXI.

Aversa, M. M. (2006). Infancia abandonada y delincuente. De la tutela provisoria al patronato público (1910-1931). En D. Lvovich y J. Suriano (comps.), Las políticas sociales en perspectiva histórica. Argentina, 1870-1952. Buenos Aires: Ungs/Prometeo.

Bailón Vásquez, F. (julio-diciembre, 2012). La Escuela Correccional de Artes y Oficios de Oaxaca, 1889-1901. Estudios de Historia Moderna y Contemporánea de México, 44, 137-173.

Barbieri, P. (2014). La arquitectura escolar. Una mirada desde la estética de la vida cotidiana. En P. Pineau (dir.), Escolarizar lo sensible. Estudios sobre estética escolar (1870-1945). Buenos Aires: Teseo.

Ben Plotkin, M. y Zimmermann, E. (comps.) (2012). Los saberes del Estado. Buenos Aires: Edhasa.

Bourquin, J. (2007). La difficile émergence de la notion d'éducabilité du mineur délinquant. Revue d'Histoire de l'Énfance "Irrégulière. Hors-série, 111-127. DoI: 10.4000/ rhei. 3010

Caimari, L. (2004). Apenas un delincuente. Crimen, castigo y cultura en la Argentina, 1880-1955. Buenos Aires: Siglo XXI.

Caimari, L. (2007). Entre la celda y el hogar. Dilemas estatales del castigo femenino (Buenos Aires, 1890-1940). Nueva Doctrina Penal, 2, 427-450.

Cabral dos Santos, M. (2006). Criança e criminalidade no inicio do século. En M. del Priore (org.), História das crianças no Brasil. São Paulo: Contexto.

Chauvaud, F. (2005). Le scandale de Mettray (1909): le trait enténébré et la campagne de presse. En L. Forlivesi et al. (eds.), Éduquer et punir. La colonie agricole et pénitentiaire de Mettray (1839-1937). Rennes: Presses Universitaires de Rennes.

Carli, S. (2002). Niñez, pedagogía y política. Transformaciones de los discursos acerca de la infancia en la historia de la educación argentina entre 1880 y 1955. Buenos Aires: UBA/ Miño y Dávila.

Carreras, S. (2005). "Hay que salvar en la cuna el porvenir de la patria en peligro...”. Infancia y cuestión social en Argentina (1870-1920). En S. Carreras y B. Potthast (eds.), Entre la familia, la sociedad y el Estado. Niños y jóvenes en América Latina (siglos XIX-XX). Madrid-Frankfurt: Iberoamericana/Vervuert. 
Castillo Troncoso, A. del (2006). Conceptos, imágenes y representaciones de la niñez en la ciudad de México, 1880-1920. México: Colmex.

Ciafardo, E. (1990). Caridad y control social. Las sociedades de beneficencia en la ciudad de Buenos Aires, 1880-1930. (Tesis de maestría). flacso, Buenos Aires.

Código Civil de la República Argentina (1923). Buenos Aires: J. Lajouane \& Cía. Editores.

Cosse, I. (2010). Pareja, sexualidad y familia en los años sesenta. Buenos Aires: Siglo XXI.

Davin, A. (1996). Growing up poor: Home, school and street in London, 1870-1914. Londres: River Oram Press.

Dekker, J. (2005). Admiration et inspiration: Mettray dans le monde européen de l'éducation surveillée. En L. Forlivesi et al. (eds.), Éduquer et punir. La colonie agricole et pénitentiaire de Mettray (1839-1937). Rennes: Presses Universitaires de Rennes.

Di Lisia, M. S. (2005). Colonias y escuelas de niños débiles. Los instrumentos higiénicos para la eugenesia en la primera mitad del siglo xx en Argentina. En M. S. Di Liscia y E. Bohoslavsky (comps.), Instituciones y formas de control social en América Latina 1840-1940. Una revisión. Buenos Aires: Prometeo/Ungs.

Forlivesi, L. et al. (eds.), Éduquer et punir. La colonie agricole et pénitentiaire de Mettray (1839-1937). Rennes: Presses Universitaires de Rennes.

Freidenraij, C. (2012). Encierro, trabajo doméstico y maternidad. Los defensores de menores ante el problema de la tutela de menores mujeres en Buenos Aires a principios del siglo xx. Trabajo presentado en las Terceras Jornadas de Estudios sobre Infancia. Vida Cotidiana, Saberes y Políticas Públicas en Argentina y Latinoamérica (1880-2010). Universidad Nacional de General Sarmiento.

Freidenraij, C. (2015). La niñez desviada. La tutela estatal sobre niños pobres, huérfanos y delincuentes. Buenos Aires, 1890-1919 (Tesis de doctorado). Ffyl-Universidad de Buenos Aires, Argentina.

García Ferrari, M. (2010). Ladrones conocidos, sospechosos reservados. Identificación policial en Buenos Aires, 1880-1905. Buenos Aires: Prometeo.

García Basalo, A. y Mithieux, M. (2017). Para seguridad y no para castigo. Origen y evolución de la arquitectura penitenciaria provincial argentina (1853-1922). San Miguel de Tucumán: Universidad Nacional de Tucumán.

Gayol, S. (2000). Sociabilidad en Buenos Aires. Hombres, honor y cafés, 1862-1910. Buenos Aires: Ediciones del Signo.

Guy, D. (2001). Girls in prison: the rol of the Buenos Aires Casa Correccional de Mujeres as an institution for child rescue, 1890-1940. En R. Salvatore et al. (ed.), Crime and punishment in Latin America. Law and society since late colonial times. Durham: Duke University Press. 
Hecht, T. (ed.). (2002). Minor Omissions. Wisconsin: University of Wisconsin.

Jablonka, I. (2005). L'éducation des jeunes détenus á Mettray et dans les colonies agricoles pénitentiaires françaises (1830-1900). En L. Forlivesi et al. (eds.), Éduquer et punir. La colonie agricole et pénitentiaire de Mettray (1839-1937). Rennes: Presses Universitaires de Rennes.

Jablonka, I. (2006). Ni père ni mère. Histoire des enfants de l'assistance publique (18741939). París: Éditions du Seuil.

Jorge, F. y Meyer Arana, A. (1908). Protección á la infancia. Antecedentes para el estudio de una ley (t. 1). Buenos Aires: Coni Hermanos.

Mases, E. (2002). Estado y cuestión indígena. El destino final de los indios sometidos en el sur del territorio (1878-1910). Buenos Aires: Prometeo-Entrepasados.

Meyer Arana, A. (1906). Colonias para menores. Bases que han servido para la organización de la Colonia de Menores Varones (Marcos Paz). Buenos Aires: Talleres Gráficos de la Penitenciaría Nacional.

Moliné de Berardoni, E. (1978). Historia de Marcos Paz: Desde sus orígenes hasta la creación del Partido-1636-1880. Buenos Aires: Archivo Histórico de la Provincia de Buenos Aires.

Nari, M. (2004). Políticas de maternidad y maternalismo político. Buenos Aires: Biblos.

Neiburg, F. y Plotkin, M. (comps.) (2004). Intelectuales y expertos, La constitución del conocimiento social en la Argentina. Buenos Aires: Paidós.

Pérez, M. (2014). Inmigración y colonización. Los debates parlamentarios en el siglo XIX. Buenos Aires: ungs/Jefatura de Gabinete de Ministros.

Pierre, É. (2005). La colonie de Mettray: exemplaire mais unique. En L. Forlivesi et al. (eds.), Éduquer et punir. La colonie agricole et pénitentiaire de Mettray (1839-1937). Rennes: Presses Universitaires de Rennes.

Pineau, P. (dir.) (2014). Escolarizar lo sensible. Estudios sobre estética escolar (1870-1945). Buenos Aires: Teseo.

Pisciotta, A. (1994). Benevolent repression. Social control and the American reformatory-prison movement. Nueva York y Londres: New York University Press.

Platt, A. (1997). Los "salvadores del niño" o la invención de la delincuencia. México: Siglo XXI.

Prieto, A. (1988). El discurso criollista en la formación de la Argentina moderna. Buenos Aires: Sudamericana.

Ríos, J. y Talak, A. (1999). La niñez en los espacios urbanos (1890-1920). En F. Devoto y M. Madero (comp.), Historia de la vida privada en Argentina, 1870-1930. Buenos Aires: Taurus. 
Rodríguez, F. (2010). Un desierto para la nación. La escritura del vacío. Buenos Aires: Eterna Cadencia.

Romero, L. A. (1994). Breve historia contemporánea de la Argentina. Montevideo: FCE.

Ruibal, B. (1993). Ideología del control social. Buenos Aires 1880-1920. Buenos Aires: CEAL.

Santillán, D. (1959). Gran Enciclopedia Argentina. Buenos Aires: Ediar.

Sarlo, B. (2003). Una modernidad periférica: Buenos Aires 1920 y 1930. Buenos Aires: Nueva Visión.

Saunier, P. (2005). Voir Mettray: l'architecture de la colonie. En L. Forlivesi et al. (eds.), Éduquer et punir. La colonie agricole et pénitentiaire de Mettray (1839-1937). Rennes: Presses Universitaires de Rennes.

Schlossman, S. (1998). Delinquent children: The juvenile reform school. En N. Morris and D. Rothman (eds.), The Oxford History of the Prison. The Practice of Punishmente in Western Society. New York: Oxford.

Schorske, C. (1987). La idea de ciudad en el pensamiento europeo: de Voltaire a Spengler. Punto de Vista, 30.

Speckman Guerra, E. (2005). Infancia es destino. Menores delincuentes en la ciudad de México (1884-1910). En C. Agostoni y E. Speckman Guerra, De normas y transgresiones. Enfermedad y crimen en América Latina (1850-1950). México: UNAM.

Terán, O. (2000). Vida intelectual en el Buenos Aires fin-de-siglo (1880-1910). Derivas de la "cultura científica". Buenos Aires: FCE.

Vianna, A. (2007). El mal que se adivina. Policía y minoridad en Río de Janeiro 1910-1920. Buenos Aires: Ad-Hoc.

Yvorel, J. (2005). Esquisse d'une histoire de la prise en charge de l'enfance délinquente aux xixe et xxe siècles. En L. Forlivesi et al. (eds.), Éduquer et punir. La colonie agricole et pénitentiaire de Mettray (1839-1937). Rennes: Presses Universitaires de Rennes.

Zapiola, M. C. (2007). La invención del menor. Representaciones, discursos y políticas públicas de menores en la ciudad de Buenos Aires, 1882-1921 (Tesis de maestría). IDAEs-UnSAM, Argentina.

Zapiola, M. C. (2013). En los albores de lo institucional. La gestación de las instituciones de reforma para menores en Argentina. En V. Llobet et al. (comp.), Pensar la infancia desde América Latina: un estado de la cuestión. Buenos Aires: CLAcso.

Zapiola, M. C. (2014). Un lugar para los menores. Patronato estatal e instituciones de corrección, Buenos Aires, 1890-1930 (Tesis de doctorado). Facultad de Filosofía y Letras-UBA, Argentina. 
Zapiola, M. C. (2015a). Educar para prevenir el mal. Las colonias rurales para menores en el imaginario de sus impulsores, Buenos Aires, comienzos del siglo xx. Historia de la Educación. Anuario. Publicación de la Sociedad Argentina de Historia de la Educación, 16(1).

Zapiola, M. C. (2015b). "Porque sólo en familia se puede formar el alma del niño". La reforma de la Colonia de Menores Varones de Marcos Paz, Buenos Aires, década de 1920. Revista de Historia de las Prisiones, 1.

Zimmermann, E. (1994). Los liberales reformistas. Buenos Aires: Sudamericana. 